\title{
Diskursus Pluralisme dalam Perspektif Hermeneutika Lintas-Iman: Penafsiran Q.S. Āli-`Imrān (3): 19 dan Yohanes 14: 6
}

\author{
Muhammad Radya Yudantiasa ${ }^{1^{*}}$ \\ 1 Gadjah Mada University, Indonesia; yudantiasa@gmail.com \\ * Correspondence
}

Received: 2021-06-29; Accepted: 2021-03-01; Published: 2021-05-25.

\begin{abstract}
This article problematizes the idea of pluralism in the Qur'an and Bible. The contestation about idea of pluralism often occurs in religion, especially in Islam and Christianity. This discourse will be analyzed using inter-religious hermeneutics perspective. This perspective shows that the relationship between the two holy books is a mutual connection. There are two options from my exploration about the idea of pluralism in the Qur'an and Bible. Firstly, make an inclusive interpretation of verses that are literally exclusive (Q.S. Äli-'Imrān (3): 19 and John (14): 6) using the hermeneutic method. Secondly, understanding the two verses literally, but we must open ourselves to dialogue with others. The second option uses the inter-religious hospitality method. Both options are very relevant if implemented in the context of diversity in Indonesia.
\end{abstract}

Keywords: al-Qur'an; Bible; inter-religious hermeneutics; pluralism.

\begin{abstract}
Abstrak: Artikel ini mencoba untuk memunculkan kembali ide-ide tentang pluralisme yang terdapat dalam al-Qur'an dan Injil. Kontestasi tentang ide-ide pluralisme sering terjadi dalam agama, khususnya di dalam agama Islam dan Kristen. Diskursus tersebut akan dianalisis dengan menggunakan perspektif hermeneutika lintas-iman. Perspektif ini menunjukkan bahwa hubungan antara kedua kitab suci tersebut merupakan hubungan ketersalingan atau mutual connection. Ada dua opsi tawaran dari hasil eksplorasi penulis terhadap ide-ide tentang pluralisme dalam al-Qur'an dan Injil. Pertama, melakukan penafsiran yang inklusif terhadap ayat-ayat yang berbunyi eksklusif (Q.S. Āli-'Imrān (3): 19 dan Yohanes (14): 6) dengan menggunakan metode hermeneutika. Kedua, memahami kedua ayat tersebut secara apa adanya dengan syarat kita harus membuka diri untuk berdialog dengan yang lainnya. Opsi kedua ini menggunakan metode inter-religious hospitality. Kedua opsi tersebut sangat relevan jika diterapkan dalam konteks keberagaman di Indonesia.
\end{abstract}

Kata Kunci: al-Qur'an; hermeneutika lintas-iman; Injil; pluralisme.

\section{Pendahuluan}

Dalam teologi agama-agama, pembagian kategori eksklusif, inklusif, dan pluralis telah banyak digunakan untuk menunjukkan karakteristik yang dimiliki oleh setiap agama. Menurut Moyaert (2011, hal. 5), pembagian tersebut digunakan untuk menjawab pertanyaan-pertanyaan yang ditujukan pada topik keselamatan. Contohnya adalah kontradiksi antara aspek universalita ${ }^{1}$ dan partikulatitas $^{2}$ dalam konsep keselamatan yang dipahami oleh Kristen tradisional. Penjelasan Moyaert tentang ketiga pembagian tersebut (eksklusif, inklusif, dan pluralis) memiliki maksud dan tujuan yang sama dengan apa yang dilakukan oleh Gavin D'Costa dalam tulisannya yang berjudul Theology of Religions (2005, hal. 627).

manusia.

${ }^{1}$ Aspek universalitas adalah adanya pemahaman bahwa Tuhan menghendaki keselamatan bagi semua umat ${ }^{2}$ Aspek partikularitas adalah adanya pemahaman bahwa keselamatan hanya datang melalui Kristus. 
Ide-ide tentang pluralisme dalam kitab suci perlu untuk diungkap kembali dalam menghadapi situasi yang semakin beragam. Interaksi antara teks dan konteks yang kreatif sangat dibutuhkan sebagai sarana untuk mengungkap nilai-nilai universal yang ingin disampaikan oleh suatu ayat dalam kitab suci. Teks yang dimaksud di sini adalah ayat-ayat dalam al-Qur'an dan Injil yang berbicara tentang pluralisme. Sedangkan konteks yang dimaksud adalah apa yang disebut oleh Lee (2005, hal. 518-520) yaitu dua hal besar dalam konteks Asia, realitas sosio-politik dan keberagaman agama. Konteks ini akan sangat tepat jika dilihat dalam perspektif dinamika keberagaman yang sedang berkembang di Indonesia.

Permasalahan yang muncul selanjutnya adalah tantangan terhadap ide pluralisme ini menuai banyak kritikan dalam internal masing-masing agama. Untuk itu, wacana yang berkembang dalam diskusi tentang pluralisme agama akan diungkapkan untuk melihat bagaimana diskusi ini berlangsung di setiap waktu. Lebih lanjut, pembaca juga bisa merasakan nuansa diskusi tersebut sekaligus bisa menilai atau bahkan memberikan kritik secara objektif terhadap diskusi yang akan disampaikan. Selain itu, tantangan yang lainnya adalah adanya ayat-ayat eksklusif yang eksis dalam kedua kitab suci tersebut. Tentu ayat-ayat eksklusif ini tidak bisa dihiraukan begitu saja. Perdebatan yang tak pernah usai di dalam masing-masing agama tersebut menunjukkan bahwa kontestasi ini akan terus menerus berlangsung sampai waktu yang tidak bisa ditentukan.

Realitas inilah yang dipandang sebagai sesuatu yang menonjol sehingga perlu untuk didiskusikan secara seksama dalam studi hermeneutika baik itu al-Qur'an maupun Injil. Ada dua hal yang perlu dikaji secara serius jika hendak melakukan upaya kontekstualisasi yang lebih relevan yaitu kesadaran sejarah dan kepekaan dalam membaca situasi kekinian (Listijabudi, 2018, hal. 209). Kekayaan tradisi budaya keagamaan yang dimiliki Indonesia menjadi nilai yang amat berharga dalam membaca situasi tersebut. Maka dari itu, kepekaan kita dalam membaca situasi tersebut menjadi sangat penting agar tidak terjadi kesalahpahaman penafsiran.

Model pembacaan yang digunakan dalam tulisan ini sebenarnya merupakan hermeneutika lintas-iman. Artinya, spirit dari kedua kitab suci tersebut akan dikolaborasikan dalam rangka menyatukan kekuatan khususnya dalam konteks keberagaman. Pembacaan ini mengharuskan pemaknaan yang liberal dari dominasi yang menghambatnya. Strategi pembacaan teks dan konteks keberagaman ini tidak saling terpisah satu dengan yang lainnya, tetapi jutru saling berkelindan dan saling berinterpretasi antara satu dengan yang lainnya (Listijabudi, 2018, hal. 210-211). Lebih lanjut, perjumpaan kedua kitab suci ini dalam level yang lebih tinggi akan menghasilkan kerja intertekstualitas yang luas dan melanjutkan hubungan lintas-iman yang lebih baik.

Beberapa penelitian sebelumnya telah melakukan kajian terhadap teks dan wacana pluralisme. Sebagaimana yang dilakukan oleh Sahiron Syamsuddin dalam salah satu artikelnya, ia mencoba mengkaji pandangan al-Quran tentang klaim eksklusif kebenaran agama. Ia melakukan reinterpretasi terhadap Q.S. al-Baqarah (2): 111-113. Menurutnya, ayat-ayat tersebut bisa menjadi landasan teologis Islam sebagai upaya untuk mencegah klaim kebenaran agama yang cenderung eksklusif (Syamsuddin, 2018, hal. 80). Selain itu, Nelson Semol Kalay juga melakukan kajian yang serupa namun berangkat dari paradigma Kristen. Ia melakukan reinterpretasi terhadap konsep Logos dan mencoba untuk menguji kembali asumsi yang mengatakan bahwa gagasan ini sangat eksklusif dan tidak mempromosikan dialog antar agama. Upaya kontekstualisasi yang ia lakukan menunjukkan bahwa konsep ini bisa diarahkan kepada wacana pluralisme bahkan bisa berkontribusi untuk pengembangan teologi pluralisme serta mendorong terjadinya dialog praksis di masyarakat (Kalay, 2019, hal. 122).

Meminjam istilah dari Sterkens, pendekatan yang digunakan di atas merupakan monoreligious approach. Karakter dari model pendekatan ini cenderung didominasi oleh tradisi keagamaan tertentu dan menggunakan basis normatif satu agama. Meskipun kajian-kajian di atas telah menunjukkan keterbukaan, tetapi pendekatan seperti ini masih menggunakan basis perspektif "kita" yang cenderung menunjukkan superioritas suatu agama. Maka dari itu, artikel ini menggunakan basis dari interreligious approach. Pendekatan ini berangkat dari paradigma pluralitas agama. Tujuan utamanya adalah untuk mengembangkan kompetensi dalam dialog. Basis normatif dari pendekatan ini adalah 
teologi pluralis. Pluralis di sini dipandang sebagai sebuah kesempatan untuk saling memperkaya (mutual enrichment) antara satu tradisi agama dengan tradisi agama lainnya (C. J. A. Sterkens, Hermans, \& Van der Ven, 1998, hal. 63).

Selain itu, artikel ini juga merupakan salah satu usaha untuk melanjutkan cita-cita dari dokumen kesepakatan bersama (a common word/kalimatun sawā) yang dideklarasikan pada tahun 2006. Dokumen ini telah disepakati oleh ratusan pemuka agama dan intelektual agama yang merupakan perwakilan dari agama Islam dan Kristen di seluruh penjuru dunia. Tujuan dari dokumen ini adalah sebagai sebuah konstitusi bersama untuk mencapai dialog antar-agama di seluruh penjuru dunia. Lebih jauh, dokumen ini merupakan titik awal untuk kerja sama dan koordinasi di seluruh dunia yang berlandaskan pada kesolidan teologi yang digali dari penafsiran terhadap al-Qur'an dan hadis dengan penafsiran terhadap Alkitab. Terlepas dari perbedaan di antara keduanya, Islam dan Kristen tidak hanya dipandang sebagai dua tradisi agama yang lahir dari nenek moyang yang sama (Abrahamic religions), tetapi keduanya dipandang sebagai dua tradisi agama yang memiliki semangat hidup berdampingan (Borrmans, 1989; Doumanis, 2012; Rahman \& Akram, 2020).

Pada bagian akhir, penulis akan memberikan pembacaan kritis sekaligus memberikan penawaran yang praktis terhadap ide-ide pluralisme yang terdapat dalam kedua kitab suci tersebut. Selain itu, penulis juga akan mencoba menerapkan ide-ide tersebut dalam konteks keberagaman Indonesia melalui cara-cara yang institusional dan dengan pendekatan-pendekatan yang lebih humanis sehingga ide-ide ini dapat diterima dengan baik oleh masyarakat. Tentu hal ini bukanlah sebuah tugas yang mudah, tetapi setidaknya usaha ini mampu berkontribusi dalam memberikan ideide lain yang lebih kreatif.

\section{Pro dan Kontra Wacana Pluraslisme dalam al-Qur'an}

Martin Riesebrodt (2010, hal. 23) dalam bukunya yang berjudul The Promise of Salvation: A Theory of Religion menawarkan sebuah teori demarkasi. Teori ini berbicara tentang keberbedaan identitas (perception of difference). Keberbedaan tersebut merupakan sebuah cara untuk menunjukkan eksistensi yang membedakan satu agama dengan agama yang lain. Jadi, suatu agama butuh identitas pembeda (demarcation) yang membedakan dirinya dengan agama lain dalam rangka untuk melihat dirinya dan juga merepresentasikan dirinya sebagai sebuah agama. Dari teori ini, penulis merenungkan kembali konsep tentang esensi dari agama. Penulis berasumsi bahwa teori demarkasi menimbulkan paradoks dalam agama. Di satu sisi, agama digunakan sebagai alat mempromosikan harmoni dan toleran. Tetapi di sisi lain, agama juga dijadikan alat justifikasi untuk membenarkan tindakan kekerasan dan sikap intoleransi. Kedua paradoks di atas akan diungkap pada bagian ini dengan menunjukkan bagaimana al-Qur'an diperlakukan dengan cara yang berbeda oleh setiap kelompok yang memiliki kepentingan tertentu.

Ali S. Asani (2019, hal. 53) berpegang pada pendapat bahwa al-Qur'an secara esensi mendukung pandangan tentang pluralitas. Tetapi, seiring dengan berjalannya waktu, al-Qur'an juga ditafsirkan oleh para kelompok eksklusif dengan tujuan-tujuan tertentu, seperti politik dan keagamaan. Dikotomi antara pluralis al-Qur'an dan anti-pluralis al-Qur'an inilah yang kita pahami sebagai kontradiksi dalam penggunaan ayat-ayat al-Qur'an. Dalam al-Qur'an, ayat yang sering dirujuk untuk menyatakan pluralitas adalah Q.S. Al-Hujurāt (49): $13 .{ }^{3}$ Lebih Lanjut, ia mengatakan bahwa tujuan diciptakannya keberagaman manusia adalah untuk saling mengetahui dan memahami. Tuhan tidak menciptakan perbedaan ini sebagai sumber perpecahan, polarisasi, dan masalah. Apakah kita sadar atau tidak, realitas ini adalah bentuk kasih sayang Tuhan kepada seluruh umat manusia (Asani, 2019, hal. 54).

Tokoh lain yang cukup gencar menyuarakan pluralisme adalah Mun'im Sirry. Ia mencoba menggali ide-ide tentang pluralisme dalam artikelnya yang berjudul "Compete with one another in good

${ }^{3}$ Wahai manusia! Sungguh, Kami telah menciptakan kamu dari seorang laki-laki dan perempuan, kemudian kami jadikan kamu berbangsa-bangsa dan bersuku-suku agar kamu saling mengenal. Sungguh, yang paling mulia di antara kamu di sisi Allah ialah orang yang paling bertaqwa. Sungguh, Allah Maha Mengetahui, Mahateliti. 
works: Exegesis of Qur'an Verse 5.48 and contemporary Muslim discourses on religious pluralism". Ia menekankan kepada teori terbaru tentang hubungan antara teks dan pembacaannya. Menurutnya, penafsiran merupakan suatu produk yang memiliki ruang dan waktunya sendiri. Dalam artikelnya, ia mencoba membandingkan penafsiran Q.S. Al-Mā'idah (5): $48^{4}$ dari tiga tokoh yaitu Nurcholish Majid, Ashgar Ali Engineer, dan Abdulaziz Sachedina. Mun'im berkesimpulan bahwa meskipun pendekatan yang mereka gunakan berbeda, (Majid lebih menekankan kepada aspek teologis, Asghar lebih menekankan aspek praktis, dan Sachedina lebih menekankan aspek politis) namun mereka semua bersepakat bahwa Al-Qur'an menyajikan pluralisme agama sebagai misteri ilahi yang harus diterima sebagai pemberian untuk memungkinkan kelancaran hubungan lintas komunitas dalam kehidupan publik (Sirry, 2009, hal. 436).

Di sisi lain, terdapat ayat-ayat al-Qur'an yang seakan-akan bertentangan dengan pandangan di atas. Seperti contohnya Q.S. Āli-'Imrān (3): 19,

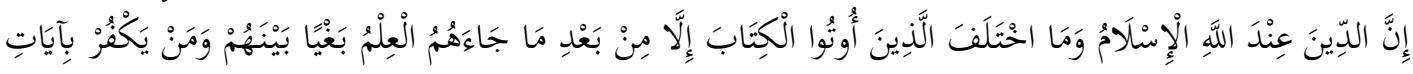

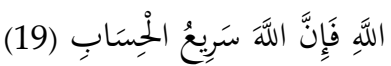

Sesungguhnya agama di sisi Allah adalah Islam. Tidaklah berselisih orang-orang yang telah diberi Kitab kecuali setelah mereka memperoleh ilmu, karena kedengkian di antara mereka. Barang siapa ingkar terhadap ayat-ayat Allah, maka sungguh Allah sangat cepat perhitunganNya.

Q.S. Āli-`Imrān (3): 85,

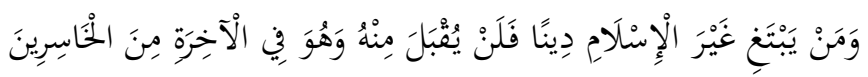

Dan barangsiapa mencari agama selain Islam, dia tidak akan diterima, dan di akhirat dia termasuk orang yang rugi.

Kedua ayat tersebut sering digunakan oleh kalangan eksklusif untuk menjustifikasi klaim kebenaran yang dimilikinya. Kalangan eksklusif menggunakan cara pandang yang sempit sehingga berimplikasi kepada bagaimana mereka menilai pandangan orang lain. Mereka sering menggunakan standar yang dibuatnya sendiri dan digunakan untuk menghakimi pandangan yang lainnya. Seperti misalnya, mereka memandang bahwa Islam adalah agama yang paling benar, sedangkan agama lainnya tidak lain adalah hasil konstruksi manusia, atau berasal dari Tuhan tetapi sudah banyak diselewengkan oleh pengikutnya sendiri (Bakar, 2016, hal. 47).

Pandangan eksklusif ini menurut Fatimah Husein dapat dikenali dengan tiga karakteristik yang melekat kepadanya. Pertama, kalangan eksklusif memahami teks-teks dalam Islam yaitu al-Qur'an dan Hadis secara literal. Hal ini berimplikasi kepada ide tentang ijtihad yang tidak penting bagi konsep pemikiran mereka. Kedua, doktrin tentang Islam merupakan jalan satu-satunya untuk menuju surga. Konsep keselamatan yang mereka gunakan sangat berbau Islam sentris sehingga mereka melakukan problematisasi terhadap kitab suci umat lain atau bahkan menolaknya. Ketiga, kesatuan antara Islam dan negara. Konsep ini sangat kuat dalam pemikiran kalangan eksklusif. Mereka menganggap bahwa ajaran Islam sudah sangat sempurna, termasuk di dalamnya urusan agama dan negara. Karakter terakhir ini didukung oleh kelompok-kelompok yang ingin menegakkan Khiläfah Islāmiyyah (Philips, 2013, hal. 54-55).

${ }^{4}$ Dan Kami telah menurunkan Kitab (Al-Qur'an) kepadamu (Muhammad) dengan membawa kebenaran, yang membenarkan kitab-kitab yang diturunkan sebelumnya dan menjaganya, maka putuskanlah perkara mereka menurut apa yang diturunkan Allah dan janganlah engkau mengikuti keinginan mereka dengan meninggalkan kebenaran yang telah datang kepadamu. Untuk setiap umat diantara kamu, Kami berikan aturan dan jalan yang terang. Kalau Allah menghendaki, niscaya kamu dijadikan-Nya satu umat (saja), tetapi Allah hendak menguji kamu terhadap karunia yang telah diberikan-Nya kepadamu, maka berlomba-lombalah berbuat kebajikan. Hanya kepada Allah kamu semua kembali, lalu diberitahukan-Nya kepadamu terhadap apa yang dahulu kamu perselisihkan. 
Kedua pandangan di atas akan selalu berkontestasi dan mungkin masih banyak lagi ayat-ayat yang bisa dijadikan sebagai alat justifikasi bagi masing-masing kelompok. Pertanyaannya adalah di mana titik temu kita dalam konteks pluralitas Indonesia? Sejarah telah menunjukkan bahwa ide pluralisme pernah dinyatakan haram oleh MUI (Majelis Ulama Indonesia) dalam fatwanya tahun 2005. Latar belakang dari fatwa ini adalah adanya prasangka yang dibangun dari pemahaman bahwa pluralisme agama yang dipromosikan telah menimbulkan keresahan di masyarakat karena pandangan ini merelatifkan agama.

Menurut Munjid, pluralisme mengalami distorsi makna dan banyak orang yang salah paham terhadap konsep ini dengan mengidentikkan pluralisme dengan relativisme. Dengan menggunakan analisis filsafat moral, ia mengatakan bahwa di satu sisi, pluralisme bisa masuk ke dalam celah-celah relativisme dalam kerangka epistemologinya. Di sisi lain, pluralisme juga bisa mengambil sikap yang tegas dalam membuat batas yang menjadi ciri absolutisme (Munjid, 2009, hal. 39). Tantangan bagi umat manusia saat ini adalah kesadaran bahwa kita semua memiliki kepercayaan. Kompetisi yang kita jalani seharusnya tidak menjadikan kita saling bertengkar antara satu dengan lainnya. Semua orang yang memiliki kepercayaan harus saling menghormati dan percaya pada semua wahyu Tuhan (Ayoub, 2014, hal. 28).

Al-Qur'an menggunakan cara-cara yang cukup progresif ketika memandang pluralisme agama. Ia mengklaim eksistensi dari kitab suci sebelumnya khususnya Taurat, Injil, dan Zabur. Hal ini dinyatakan dalam Q.S. Al-Baqarah (2): 62,

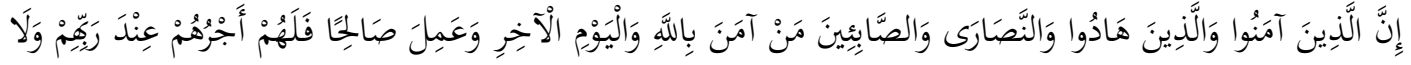

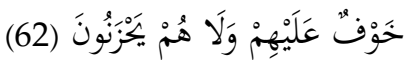

Sesungguhnya orang-orang yang beriman, orang-orang Yahudi, orang-orang Nasrani dan orang-orang Sabiin, siapa saja (di antara mereka) yang beriman kepada Allah dan hari akhir, dan melakukan kebajikan, mereka mendapat pahala dari Tuhannya, tidak ada rasa takut pada mereka, dan mereka tidak bersedih hati.

Q.S. Al-Mā'idah (5): 69 :

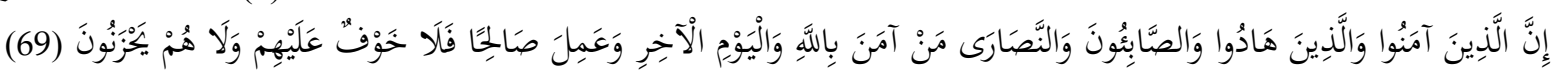

Sesungguhnya orang-orang yang beriman, orang-orang Yahudi, Sabiin, dan orang-orang Nasrani, barangsiapa beriman kepada Allah, kepada hari kemudian, dan berbuat kebajikan, maka tidak ada rasa khawatir padanya dan mereka tidak bersedih hati.

Kedua ayat tersebut menunjukkan pluralitas agama dan juga pluralitas kitab suci lainnya. Selain itu, pluralitas agama dan kitab suci juga dapat diinisiasikan dari banyaknya jumlah nabi dan rasul yang saling mengikuti antara satu dengan yang lainnya semenjak nabi Adam hingga nabi Muhammad (Iqbal, 2018). Ini menunjukkan sebuah rangkaian yang menjadi satu kesatuan yang utuh. Sejarah manusia, menurut pandangan al-Qur'an merupakan sejarah kenabian. Dalam realitasnya, sejarah kenabian merupakan sejarah tuntunan umat manusia kepada Tuhan melalui misi yang dilakukan oleh nabi dan Rasul (Ayoub, 2014, hal. 22-24).

\section{Pergulatan Konsep Pluralisme dalam Kristen}

Dalam teologi Kristen, wacana tentang pluralisme juga menjadi isu yang cukup diperdebatkan dalam teologi mereka. Seperti yang penulis sampaikan di pendahuluan yaitu adanya perbedaan antara aspek universalitas dan partikularitas dalam hal keselamatan. Bagaimana memahami problem demikian? Bagaimana perdebatan konsep pluralisme dalam Kristen? Pertanyaan-pertanyaan tersebut akan dieskplorasi lebih dalam di bagian ini. 
Beberapa tema yang menjadikan teologi Kristen terlihat eksklusif adalah isu kristologi ${ }^{5}$, soteriologi $^{6}$, dan ekklesiologi. ${ }^{7}$ Sebagai bagian yang penting dalam teologi Kristen, ketiga konsep tersebut saling berhubungan antara satu dengan yang lainnya. Seperti misalnya, ketika konsep kristologi terkesan eksklusif, maka konsep tersebut akan berdampak pula pada konsep soteriologi. Rujukan yang sering digunakan adalah umat Kristen percaya bahwa Kristus adalah satu-satunya jalan keselamatan (Yoh. 3:16-17). Tidak ada jalan lain kecuali di dalam Kristus, di mana manusia memperoleh keselamatan di dalam Tuhan (Kis. 4:12; 16:30-31). Pemahaman seperti ini selanjutnya diikuti dengan upaya-upaya untuk melakukan Kristenisasi agar banyak orang yang lebih percaya kepada Kristus. Hal ini juga merupakan "Amanat Agung" yang dipegang teguh oleh umat Kristen (Objantoro, 2016, hal. 64-68).

Tafsir tentang "Amanat Agung" yang secara tekstual dipahami sebagai suatu misi yang agresif untuk memberitakan Injil dipahami dengan lebih terbuka oleh Listiabudi. Ia menggunakan analisis dari Soares-Prabhu yang merupakan seorang teolog asal India dan menulis artikel terkenal berjudul "Two Mission Commands: An Interpretation of Matthew 28:16-20 in the Light of a Buddhist Text". Pada intinya, tulisan ini mencoba untuk membandingkan dua teks perintah dari tradisi Kristen dan Buddhis. Kesimpulan dari artikel ini menunjukkan bahwa teks Buddhis berhasil mengiluminasi teks Injil, khususnya teks Matius. Sebenarnya pembacaan ini merupakan "cross-religious reading" yang mengarah kepada kerja intertekstualitas yang lebih memperkaya pemahaman dengan cara beinteraksi dengan teks dari tradisi agama lain (Listijabudi, 2018, hal. 222-227).

Semangat ini diperkuat oleh argumentasi yang diajukan oleh Paul Knitter. Ia mengusulkan perubahan paradigma yang disebut dengan posisi pluralis. Pandangan ini merupakan sebuah upaya untuk meninggalkan paham yang menekankan pada superioritas dan finalitas Kristus. Pertanyaan menarik yang ia sampaikan adalah "How might assertions about "the only Savior" or "the highest enlightenment" or "the final revelation" be understood and reformulated so that each religious community can make room for other communities in today's pluralistic community and religions?" (Knitter 2005). Pertanyaan ini sangat relevan untuk ditanyakan dalam konteks kehidupan bernegara di Indonesia (Afsaruddin, 2009, hal. 333).

Dalam konteks kehidupan berbangsa dan bernegara, Arya Susanti (2017, hal. 87) mengkaji tentang relevansi finalitas Kristus bagi teologi al-Kitab dan bagi kehidupan orang-orang Kristen di tengah-tengah kehidupan majemuk bangsa Indonesia. Ia mengatakan bahwa relevansi finalitas Kristus dengan beberapa pertimbangan waktu, pengajaran, dan sejarah kehidupan menjadikan finalitas Kristus berlaku untuk jangka waktu yang tidak terbatas. Selain itu, dalam konteks pluralitas bangsa ini, maka toleransi dan dialog menjadi kata kunci sebagai representasi dari konsep "kasih" dalam agama Kristen. Konsep tentang relevansi finalitas Kristus dalam setiap zaman dan waktu ini memiliki semangat yang sama dengan al-Qur'an yang dipedomani oleh umat Islam. Menurut penulis, kedua semangat ini merupakan potensi besar untuk membangun kehidupan bersama. Artinya, jikalau kedua agama ini memiliki klaim yang sama, maka mereka punya nilai-nilai universal yang sama untuk memperbaiki kehidupan dari waktu ke waktu.

Konsep pluralisme dalam agama Kristen juga menuai banyak kritikan dari para penganutnya. Seperti yang dikatakan oleh Stevri I. Lumintang, pluralisme merupakan ancaman bagi agama Kristen,

Pluralisme adalah suatu tantangan sekaligus bahaya yang sangat serius bagi kekristenan. Karena pluralisme bukan sekedar konsep sosiologis, antropologis, melainkan konsep filsafat agama yang bertolak bukan dari Alkitab, melainkan bertolak dari fakta kemajemukan yang diikuti oleh tuntutan toleransi, dan diilhami oleh keadaan sosial-politik yang didukung oleh kemajemukan etnis, budaya dan agama; serta disponsori oleh semangat globalisasi dan filsafat relativisme yang mengiringinya (Lumintang, 2004, hal. 15).

${ }^{5}$ Kristologi merupakan paham yang meyakini bahwa Kristus adalah pribadi yang sempurna. Ia memiliki posisi yang unik dan istimewa di kalangan umat Kristen.

${ }^{6}$ Soteriologi merupakan paham yang meyakini bahwa Yesus adalah satu-satunya jalan keselamatan.

${ }^{7}$ Ekklesiologi merupakan paham yang meyakini otoritas gereja sebagai otoritas tertinggi. Doktrin tentang gereja berperan penting dalam hidup orang-orang yang percaya 
Pandangan pluralisme ini berpijak pada teologi liberal. Kaum pluralis memberikan kritik yang tajam terhadap proses pewahyuan al-Kitab. Mereka berpendapat bahwa penulisan al-Kitab merupakan hasil pemahaman atau interpretasi dari para penulisnya (Soesilo, 2011, hal. 5). Terdapat banyak versi pemahaman terkait dengan kapan dan bagaimana awal mula munculnya ide tentang hermeneutika. Pandangan di atas merupakan salah satu versi dari munculnya ide-ide tentang hermeneutika. Sebagaimana yang kita pahami secara seksama bahwa ide hermeneutika merupakan suatu tradisi penafsiran yang muncul dari Kristen.

Dalam pendahuluan, saya telah menyinggung sedikit tentang hermeneutika Asia. Di sini, Yudhak Soesilo (2011, hal. 8) mengatakan bahwa konsep pluralisme di Indonesia harus dipahami dalam model berpikir pemikir-pemikir pluralis Asia. Terdapat kesamaan argumentasi yang mendasar antara kerja hermeneutika Asia dan pluralisme Asia. Keduanya sama-sama berangkat dari situasi kemajukan dalam hal agama, budaya, politik, dan ekonomi. Menurut penulis, semangat yang sama ini bisa dikolaborasikan bersama dalam rangka membaca kitab suci dalam konteks keberagaman Indonesia. Salah satu yang diusulkan oleh tokoh Pluralis Asia yaitu teologi transposisional. Transposisi bisa dipahami sebagai pergeseran ruang dan waktu, komunikasi, dan inkarnasi (Song, 2008, hal. 7-17). Salah satu pandangan teologi transposisional yaitu konsep keselamatan yang sangat terbuka. Jika keselamatan itu berasal dari Tuhan, maka mengakui keselamatan yang lainnya seharusnya juga terbuka. Hal ini sesuai dengan Efesus (Ephesians) 2: 8-9.

Pandangan di atas berhadapan dengan beberapa tokoh eksklusif seperti Samuel Zwemer, Hendrik Kraemer, and Lesslie Newbigin yang mengikuti salah satu konsep berpikir dari Aristoteles yaitu kebenaran hanyalah satu dan tidak banyak. Kelompok Eksklusif menganggap bahwa semua klaim religius selain Kristen adalah salah dan tidak valid. Mereka berpegang pada pendapat bahwa keselematan hanya melalui Yesus semata. Pandangan ini bermula dari pemahaman terhadap Bible sebagai satu-satunya sumber spiritualitas dan keselamatan (Marbaniang, 2007, hal. 6-7). Pandangan ini didukung oleh beberapa ayat dalam Bible seperti Kisah Para Rasul (Acts) 4: $12^{9}$, Kisah Para Rasul (Acts) 16: 30-31 ${ }^{10}$, and Yohanes (John) 14: $6 .{ }^{11}$ Selain itu, pandangan di atas juga di dukung dengan ekspresi yang terungkap dalam kalimat "Extra Ecclesiam mulla salus" (No salvation outside the Church) (Philips, 2013, hal. 52).

Dua tokoh lain yang memiliki pandangan tentang eksklusivisme adalah Karl Barth dan Hendrik Kraemer. Karl Barth mengatakan bahwa tidak ada pengetahuan tentang Tuhan yang dapat ditemukan diluar Yesus. Sedangkan Hendrik Kraemer mengatakan bahwa Tuhan bisa saja memberikan wahyu diluar Kristen, tetapi kebenaran hanya bisa ditafsirkan melalui Yesus. Pandangan Barth menurut Knitter dapat dikategorikan sebagai "the conservative evangelical model". Sedangkan pandangan Hendrik Kraemer sedikit lebih moderat meskipun pada akhirnya tetap berpegang pada eksklusivisme. Ada dua hal yang mendasari konsep teologi eksklusif Barth. Pertama, berkembangnya pengaruh dari relativisme di setiap bidang keilmuan termasuk teologi. Kedua, hilangnya hak setiap agama sebagai "sole interpreter of the universe" karena disebabkan oleh kesamaan agama-agama (Philips, 2013, hal. 52-53).

Ada kesamaan kritik terhadap konsep pluralisme dalam Islam dan Kristen, yaitu relativisme. Kritik ini memandang pluralisme sebagai konsep yang merelatifkan agama-agama. Namun, kalangan pluralis juga membela diri dengan mengatakan pluralisme tidak sama dengan relativisme. Diskusi di atas menunjukkan bagaimana pergulatan konsep tentang pluralisme terjadi. Masing-masing kelompok memiliki argumentasi yang saling bertentangan satu dengan yang lainnya. Lalu pertanyaannya adalah bisakah kita menafsirkan ayat-ayat dalam Bible yang eksklusif dengan cara

${ }^{8}$ Sebab karena kasih karunia kamu diselamatkan oleh iman; itu bukan hasil usahamu, tetapi pemberian Allah, itu bukan hasil pekerjaanmu: jangan ada orang yang memegahkan diri.

${ }^{9}$ Dan keselamatan tidak ada di dalam siapa pun juga selain di dalam Dia, sebab di bawah kolong langit ini tidak ada nama lain yang diberikan kepada manusia yang olehnya kita dapat diselamatkan.

${ }^{10}$ Ia mengantar mereka keluar, sambal berkata: "Tuan-tuan, apakah yang harus aku perbuat, supaya aku selamat?" Jawab mereka: "Percayalah kepada Tuhan Yesus Krsitus dan engkau akan selamat, engkau dan sisi rumahmu."

${ }^{11}$ Kata Yesus kepadanya: "Akulah jalan dan kebenaran dan hidup. Tidak ada seorang pun yang datang kepada Bapa, kalau tidak melalui aku." 
yang inklusif? Pertanyaan ini penulis ungkapkan karena argumentasi yang digunakan oleh kalangan eksklusif juga didukung oleh ayat-ayat yang ada di dalam Bible. Untuk itu, pada bagian selanjutnya penulis akan mencoba menggunakan pendekatan hermeneutika untuk menafsirkan sebuah ayat dalam Bible yang bernada eksklusif.

\section{Metode Hermeneutika: Upaya Memahami Ayat-ayat Eksklusif dengan Lebih Terbuka}

Setelah membahas tentang diskusi, kontestasi, dan juga argumentasi dari masing-masing agama terhadap konsep pluralisme, pada bagian ini penulis akan mencoba untuk mengaplikasikan metode hermeneutika untuk membaca teks-teks yang berbunyi eksklusif. Penulis tidak menggunakan metode hermeneutika yang sama dalam mengkaji kedua kitab suci tersebut dengan dua alasan. Pertama, karena adanya konsep teologis yang berbeda dalam masing-masing kitab suci. Kedua, para sarjana sudah menyesuaikan metode yang digunakannya sesuai dengan karakteristik masing-masing kitab suci.

Ada dua teks yang akan dikaji pada bagian ini. Pertama adalah teks al-Qur'an yaitu Q.S. Āli'Imrān (3): 19 dan kedua adalah teks Injil yaitu Yohanes (14): 6. Secara umum, kedua ayat ini digunakan karena mengindikasikan pandangan eksklusif. Dalam al-Qur'an, ayat tersebut secara tekstual menyatakan bahwa agama di sisi Allah adalah Islam. Sedangkan dalam Injil, ayat tersebut juga mengindikasikan pandangan eksklusif karena menyatakan bahwa Yesus adalah satu-satunya jalan kebenaran. Kedua teks tersebut sama-sama mengklaim kebenaran yang mereka miliki. Maka dari itu, bagian ini akan mencoba untuk melakukan interpretasi untuk memahami kedua ayat di atas dengan lebih terbuka dan berbeda dengan pandangan eksklusif.

Adapun metode hermeneutika yang digunakan untuk memahami teks al-Qur'an adalah metode

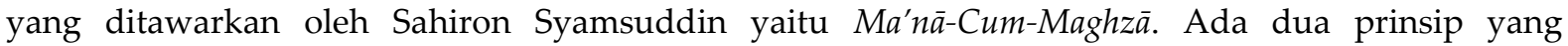
digunakan dalam pendekatan ini. Pertama, penafsir harus memperhatikan makna asli dari sebuah teks (al-Qur'an) sebagaimana makna ini dipahami oleh audiens pada saat al-Qur'an diturunkan $\left(M a^{\prime} n \bar{a}\right)$. Kedua, mengembangkan signifikansi teks ke dalam situasi kontemporer saat ini (Maghzā). Pendekatan ini juga mensyaratkan untuk memahami konteks historis dari ayat tersebut. Dalam Islam, tradisi ini disebut dengan Asbāb al-Nuzūl (latar belakang turunnya ayat). Jadi, intinya ada dua hal yang harus dilakukan, yaitu analisis bahasa dari ayat yang dikaji dan konteks sosio-historis ayat tersebut yang digunakan untuk memahami makna historis yang selanjutnya dapat memberikan makna yang baru (Syamsuddin, 2018, hal. 69-72).

Sedangkan untuk memahami Yohanes (14): 6, penulis menggunakan pendekatan ideologis (ideological approach). Pendekatan ini memiliki peran yang sangat penting dalam pembebasan teologi (liberation theologies) dan pembacaan teks-teks (materialist readings) Injil. Pendekatan Ideologis terhadap Injil mensyaratkan dua hal yang harus dipahami yaitu "(1) to read the ancient biblical stories for their ideological content and mode of production and (2) to grasp the ideological character of contemporary reading strategies" (Aichele, 1995, hal. 277). Sebenarnya pendekatan ini mengindikasikan bahwa setiap elemen dari hermeneutika (text, author, and reader) memiliki ideologi. Hubungan antara ketiganya tidak pernah murni dan bebas dari ideologi. Artinya, selalu ada bias baik itu dari sisi pengarangnya, teks itu sendiri dan juga pembaca.

Pendekatan ini dapat menjadi sebuah jembatan antara kritik sastra dan kritik budaya. Ia tidak datang dari sesuatu yang seragam, tetapi ia datang dari berbagai macam suara, bahasa, dan juga menggunakan berbagai macam pendekatan ilmu (psychoanalytic theory, cultural criticism, sociolinguistics, subaltern studies, feminist theory) (Aichele, 1995, hal. 280). Selain itu, pendekatan ini juga tidak bisa terhindar dari ketegangan pembacaan (resistance reading). Pembacaan ini menunjukkan kepada keterbukaan pada suatu teks dan konsekuensinya adalah tidak ada makna yang absolut. Hal ini mendukung diktum dari Bultmann yang mengatakan "there are no presuppositionless readings of the New Testament. Resistant readings are always shaped by political interest" (Aichele, 1995, hal. 302). Untuk memahami Yohanes (14): 6, penulis hanya fokus kepada pertanyaan, siapa yang menulis teks ini? Dan untuk tujuan apa? Pertanyaan tersebut akan mengantarkan kepada pemahaman ideologi penulis teks tersebut dan juga terhadap teks itu sendiri. 


\section{Q.S. Āli-'Imrān (3): 19}

Penulis hanya akan fokus terhadap makna Dìn dan Islām yang terdapat dalam ayat ini. Perbedaan penafsiran terhadap kata tersebut sering terjadi. Terutama tentang bagaimana cara menafsirkan kata Dìn dan Islām dengan pemahaman yang lebih inklusif. Secara umum, ayat ini seringkali ditafsirkan bahwa Islam merupakan agama yang paling benar di sisi Allah dan disyariatkan kepada Nabi Muhammad. Untuk itu, penulis akan mencoba memahami ayat ini dengan menggunakan metode $M a^{\prime} n \bar{a}-C u m-M a g h z \bar{a}$. Pertama, kita harus menuju kepada makna asli dari kata Dìn dan Islām. Kata Dìn bemakna agama dan juga dapat dipahami dengan Millah. Sedangkan kata Islām bermakna tunduk atau berserah diri. Ibnu 'Asyūr, salah seorang penafsir modern menafsirkan kata Islam dengan ketaatan total manusia terhadap perintah Tuhan (Syamsuddin, 2018, hal. 74).

Dalam analisis sinonimitas, kata Dìn bermakna Millah dan Syarī'ah. Secara umum, ketiganya memiliki makna yang sama jika ditinjau dalam aspek takliff (beban tanggung jawab manusia kepada Tuhan). Teori sinonimitas merupakan sebuah analisis linguistik yang menunjukkan kepada hubungan semantik yang menyatakan adanya kesamaan arti antara satu kesatuan ujaran dengan ujaran lainnya. Jadi, relasi makna sinonimi merujuk pada konteks sinonimitas dalam pengambilan maknanya. Prinsip dari teori ini adalah ayat-ayat yang mengandung unsur sinonim tidak bisa dipertentangkan karena makna dari ketiga kata di atas bisa disubtitusikan antara satu dengan yang lainnya (Nurhadi, Hadi, Thoyib, \& Suhandano, 2013, hal. 65-66).

Analisis sinonimitas ini sangat membantu dalam memahami ayat-ayat yang tampak saling bertentangan antara satu dengan yang lainnya. Seperti misalnya, sinonimitas kata Din dalam ayat ini dengan kata Syarī'ah dalam Q.S. Al-Mā'idah (5): 48 yang menuntut pemaknaan kata Islām dalam ayat ini kepada makna generiknya yaitu tunduk atau berserah diri, bukan dimaknai sebagai Islam dalam pengertian institusionalized religion. Jadi, Dìn di sisi Allah hanyalah tunduk dan berserah diri. Sedangkan Syaríah yang diciptakan kepada setiap umat juga disebut dengan Dìn. Pemahaman kata Dìn dengan analisis ini akan menimbulkan hubungan ketersalingan dengan Q.S. Al-Mā'idah (5): 48 (Nurhadi et al., 2013, hal. 66).

Pemahaman dengan menggunakan teori sinonimitas ini bisa menghadirkan pandangan Islam yang inklusif. Dalam aspek keselamatan, pemahaman ini mengindikasikan bahwa surga tidak dimonopoli bagi beberapa kelompok saja, tetapi ia dimiliki oleh semua yang tunduk kepada Allah. Hal ini sesuai dengan Q.S. Al-Baqarah (2): 62 yang dipahami dengan semua penganut agama ilahiah (yang diwahyukan Tuhan), apabila mereka beriman pada Allah dan hari akhir dengan cara yang benar, mereka akan mendapatkan keselamatan dan mendapat balasan di sisi Allah. Jadi, keselamatan tidak berdasarkan pada jenis agamanya, tapi tergantung pada iman dan amalnya.

Pemahaman seperti ini menjadi cukup signifikan jika ditinjau dari sisi pluralitas masyarakat Indonesia. Umat Islam membutuhkan teologi Islam pluralis yang bisa menangani problem klaim kebenaran agama. Teori sinonimitas yang dijelaskan di atas juga membantu untuk menghindarkan pertentangan antar ayat bahkan bisa menafsirkan antara ayat yang dipandang eksklusif dengan ayat yang inklusif. Jadi signifikansi (Maghzā) dari ayat ini adalah semua yang berserah diri kepada Tuhan Yang Maha Esa dan melakukan perbuatan baik akan selamat.

Yohanes (14): 6

Untuk memahami teks ini, penulis memfokuskan kepada dua hal yaitu sejarah penulisnya dan juga konteks ketika ia menulis teks ini. Dua hal tersebut diharapkan bisa digunakan untuk memahami ideologi dari penulis dan juga ideologi teks. Tidak ada informasi yang mutlak tentang siapa yang menulis dan kapan teks ini ditulis. Ada yang berpendapat bahwa teks ini ditulis oleh Rasul Yohanes (the Apostle John). Namun, para ahli Perjanjian Baru modern membantah hal tersebut. Menurut mereka, teks ini ditulis oleh para pengikut atau murid Yohanes. Mereka berargumen bahwa teks ini ditulis pada akhir abad pertama. Pada masa ini, Yohanes telah wafat. Selain tu, dalam kajian Perjanjian baru juga dikenal istilah pseudepigraphy. Istilah ini merujuk kepada karya yang dikaitkan secara keliru atau teks yang pengarangnya bukan pengarang yang sebenarnya. Bagaimamapun, pada 
dasarnya teks ini adalah catatan yang terilhami dari kehidupan Yesus. Tujuan utama catatannya adalah untuk memberikan bukti bahwa Yesus Kristus adalah figur yang harus kita percayai untuk diselamatkan (Aquinas, 2012, hal. 9-10).

Dibandingkan dengan ketiga injil lainnya yaitu injil-injil Sinoptik (Matius, Markus, dan Lukas), Injil Yohanes mendeskripsikan Yesus sebagai pribadi yang agak misterius dan diliputi dengan sentuhan mistik. Penulis buku ini sangat menyukai istilah hidup kekal. Salah satu perbedaan yang mencolok antara Injil Sinoptik dan Injil Yohanes adalah Injil Sinoptik lebih menekankan kepada pewartaan tentang kerajaan Allah, sedangkan Injil Yohanes menekankan kepada Yesus itu sendiri. Pribadi Yesus ditafsirkan dengan cara-cara yang berbeda dengan pemahaman injil-injil Sinoptik. Seperti contohnya, penulis Injil Yohanes menjelaskan Yesus dengan ucapan-ucapan yang diucapkan oleh Yesus sendiri. Ciri-cirinya adalah adanya tujuh perkataan Yesus yang mengatakan "aku adalah". ${ }^{12}$

Konteks situasi yang penting untuk dilihat adalah Injil Yohanes sangat berkaitan dengan situasi ketika masyarakat Yahudi mengucilkan orang-orang Kristen keturunan Yahudi. Situasi ini juga memungkinkan komunitas Yohanes terdiri dari orang-orang dengan latar belakang Yahudi diaspora. Berhadapan dengan situasi seperti ini, maka komunitas ini membutuhkan kekuatan untuk mengukuhkan kesatuan diantara mereka sendiri yaitu persatuan iman terhadap Yesus. Kondisi ini sejalan dengan tujuan ditulisnya Injil Yohanes dan juga sejalan dengan karakter-karakter yang melekat dalam Injil ini. Penjelasan singkat di atas paling tidak bisa menjawab pertanyaan yang diusulkan yaitu siapa yang menulis kitab ini dan untuk tujuan apa.

Selanjutnya, penulis akan mencoba memahami dari sisi penafsiran terhadap ayat ini sendiri. Teks ini berbunyi, Kata Yesus kepadanya: "Akulah jalan dan kebenaran dan hidup. Tidak ada seorang pun yang datang kepada Bapa, kalau tidak melalui aku." Kata "jalan" ternyata memiliki penafsiran yang cukup beragam. Ada pendapat yang mengatakan bahwa kata ini dipahami sebagai jalan untuk mencapai surga. Pendapat ini kemungkinan benar jika dipahami oleh pengikut Yohanes dengan sudut pandang mistik. Kemungkinan latar belakang lainnya mengatakan bahwa kata "jalan" bermakna Highway to Zion. Hal ini cukup masuk akal karena referensi sebelumnya menunjukkan bahwa "jalan" dalam konteks ini menyatakan suatu eksodus baru, yang dengannya Allah akan mengembalikan umatnya ke tanah suci. Dalam tradisi Biblikal, khususnya tentang kebijaksanaan, "jalan" dipahami sebagai jalan kebajikan dan kebijaksanaan. Sumber-sumber Yahudi awal juga menunjukkan kata tersebut kepada kelakukan (tindak-tanduk) (Keener, 2003, hal. 940).

Kata "kebenaran" dan "hidup" berfungsi untuk sekedar mengklarifikasi kata "jalan". Kebenaran dalam tradisi yahudi dipahami sebagai moral integrity. Sedangkan kehidupan di pahami sebagai way of behavior. Kemunculan klaim ini dalam Injil keempat tidak bisa dilepaskan dari polemik terhadap orang-orang Yahudi, khususnya politik agama Yahudi dan para elit keagamaan (the Jewish political and religious elite). Secara etnis, pada mulanya orang-orang Kristen adalah universalis. Konteks ini sangat penting untuk dipahami karena berkaitan dengan bagaimana menafsirkan teks ini secara lebih terbuka. Bagaimanapun, teks yang secara literal eksklusif ini tidak menutup kemungkinan adanya jalan lain. Klaim ini lebih bersifat universal (Keener, 2003, hal. 943).

\section{Inter-Religious Hospitality: Cara Baru Memahami Pluralisme dalam Konteks Indonesia}

Dua penafsiran di atas merupakan contoh bagaimana menafsirkan ayat-ayat yang secara literal berbunyi eksklusif dengan cara yang inklusif. Beberapa sarjana dalam masing-masing agama sudah banyak yang mencoba memahami ayat-ayat yang secara literal ekslusif menjadi lebih inklusif dengan metode hermeneutika. Tetapi, apa yang mereka lakukan banyak menuai kritikan dari berbagai macam kalangan. Hal ini karena pemahaman yang mereka gunakan bisa dikatakan sebagai sesuatu yang berbeda dengan kebiasaan yang dianut (out of the box). Model pemahaman di atas menjadi opsi pertama yang bisa digunakan sebagai wacana untuk memahami isu pluralisme. Pada bagian ini,

12 Yohanes 6: 35, 8: 12, 10: 7, 10: 11, 11: 25, 14: 6, dan 15: 1 
penulis akan mengekplorasi opsi kedua yang bisa digunakan sebagai wacana lain untuk memahami pluralisme yaitu dengan metode inter-religious hospitality (keramahtamahan lintas-agama).

Hal penting yang perlu dipahami dalam konteks inter-religious hospitality adalah bahwa setiap teks memiliki dunianya sendiri. Ia memiliki tradisi yang spesifik dan tentunya juga memiliki pandangan dunia (world view) yang khas. Inilah yang harus dipahami ketika menjumpai adanya perbedaan. Dalam konteks ini, perbedaan-perbedaan yang muncul tidak digunakan sebagai alat untuk melemahkan yang lain. Tetapi, perbedaan ini seharusnya mampu menjadi suatu kekuatan yang mempersatukan. Hal ini harus didasari kepada kesadaran bahwa pihak lain (religious other) juga memiliki kebanggaan dan keyakinan, komitmen iman, dan tradisi religiusnya sendiri (Moyaert, 2011, hal. 235).

Pihak lain (religious other) tidak dipahami sebagai orang miskin (orang yang membutuhkan), tetapi pihak lain dipandang sebagai orang yang kaya. Orang kaya memiliki sesuatu yang bisa dibagikan kepada yang lainnya. Jadi, mereka hanya meminta kita untuk menerima pemberiannya dengan ramah dan mendengar serta memahami maksud yang mereka inginkan. Satu hal yang menjadi motivasi penting bagi dialog lintas-iman adalah pengalaman keberagaman agama sebagai sumber kekayaan spiritual dan moral (Moyaert, 2011, hal. 265). Gambaran di atas sangat tepat jika digunakan pada opsi kedua dalam memahami kedua teks dalam al-Qur'an dan Bible. Kita bisa memahami kedua ayat tersebut tanpa harus melakukan penafsiran yang terbuka. Yang perlu dilakukan adalah diri kitalah yang harus membuka diri. Dengan demikian, kita tidak akan memiliki masalah dengan keimanan masing-masing.

Tentu ada konsekuensi-konsekuensi yang harus kita hadapi ketika kita membuka ruang bagi yang lain. Maka dari itu, kita harus siap dengan teologi dalam diri kita sendiri. Usaha ini membutuhkan keseriusan untuk membentuk teologi yang valid. Resiko yang terjadi ketika melakukan dialog lintas-iman seharusnya tidak menjadikan kita tidak peduli, pasif, atau bahkan menghindar darinya. Sebaliknya, kita harus mengolah ketegangan yang terjadi secara dialektis. Kita dapat memperjuangkan koneksi mutual untuk mengembangkan pemahaman dan berdialog dengan cara berkomitmen dengan keimanan kita masing-masing dan terbuka terhadap pihak lainnya (Listijabudi, 2019, hal. 83). Ide ini mirip dengan gagasan yang disampaikan oleh Calvin E. Shenk tentang simbiosis agama. Ia juga menawarkan paradigma dialog antar agama. Gagasan ini di satu sisi menekankan kepada praksis kesaksian iman, namun di sisi lain gagasan ini juga tidak bisa mengabaikan bahwa setiap agama saling membutuhkan (Parihala \& Sapteno, 2020, hal. 113).

Pemahaman di atas seharusnya bisa diterima oleh masyarakat luas. Dalam konteks kehidupan berbangsa dan bernegara di Indonesia, keterbukaan terhadap pihak lain sangat dibutuhkan. Interreligious hospitality telah menunjukkan bahwa kita bisa berkomitmen dengan keimanan kita masingmasing sekaligus memahami keimanan pihak lain. Penulis yakin model dialog seperti ini akan menjadikan keragaman di Indonesia semakin solid, aman, dan tercipta kehidupan yang damai.

\section{Kesimpulan}

Wacana pluralisme bukan sesuatu yang baru dalam diskusi teologi agama-agama. Pembahasan di atas menunjukkan bahwa wacana ini selalu menjadi perdebatan yang cukup sengit dalam agama Islam dan Kristen. Artikel ini berusaha untuk memunculkan kembali wacana tentang pluralisme dalam sudut pandang inter-religious hermeneutics. Perspektif ini digunakan karena masing-masing kitab suci memiliki pengalaman yang sama yaitu realitas sosio-politik dan keberagaman agama. Pengalaman tersebut akan menunjukkan kepada hubungan keterlasingan ketika digunakan dalam konteks Indonesia. Ada dua opsi yang bisa digunakan dalam wacana pluralisme ini. Pertama, menafsirkan ayat-ayat yang secara literal eksklusif dengan cara yang inklusif. Opsi pertama ini menggunakan metode hermeneutika untuk mengungkap makna-makna yang ada di balik kedua kitab suci tersebut. Hasilnya adalah ayat-ayat-eksklusif dalam kedua kitab suci tersebut bisa dipahami secara inklusif dan berbeda dengan makna literalnya. Opsi kedua menggunakan metode inter-religious hospitality (keramahtamahan lintas-iman). Metode ini lebih menekankan kepada diri kita sendiri yang harus membuka diri. Karena teks pada dasarnya memiliki dunia sendiri dan 
keunikannya sendiri. Jadi, ayat-ayat yang secara literal berbunyi eksklusif tersebut bisa dipahami dengan apa adanya tetapi tidak membatasi kita untuk melakukan dialog dengan yang lainnya. Metode ini menunjukkan bahwa kita bisa berkomitmen dengan keimanan kita masing-masing di satu sisi, dan kita juga bisa berdialog dengan yang lainnya.

\section{Referensi}

Afsaruddin, A. (2009). The Hermeneutics of Inter-Faith Relations: Retrieving Moderation and Pluralism as Universal Principles in Qur'anic Exegeses. Journal of Religious Ethics, 37(2), 331-354. https://doi.org/10.1111/j.1467-9795.2009.00389.x

Aichele, G. (1995). The Postmodern Bible. New York: Yale University.

Aquinas, T. (2012). Commentary on the Gospel of John. https://doi.org/10.2307/j.ctt31nk8p

Asani, A. S. (2019). The Phi Beta Kappa Society. In The Grants Register 2019 (Vol. 71, hal. 595-595). https://doi.org/10.1007/978-1-349-95810-8_953

Ayoub, M. (2014). Religious Pluralism and The Qur'an. In I. Yusuf (Ed.), Asean Religious Pluralism. Bangkok: Konrad-Adenauer-Stiftung Thailand Office.

Bakar, A. (2016). Argumen Al- Qur'an tentang Eklusivisme, Inklusivisme, dan Pluralisme. Toleransi: Media Komunikasi Umat Beragama, 8(1), 43-60.

Borrmans, M. (1989). Future prospects for Muslim-Christian coexistence in non-Islamic countries in light of past experience. Institute of Muslim Minority Affairs. Journal, 10(1), 50-62. https://doi.org/10.1080/02666958908716101

D'Costa, G. (2005). Theology of Religions. In D. F. Ford (Ed.), The Modern Theologians (3 ed., hal. 626-644). https://doi.org/10.1111/dial.12406

Doumanis, N. (2012). Before the nation: Muslim-Christian coexistence and its destruction in late-Ottoman Anatolia. Oxford: OUP Oxford.

Iqbal, A. M. (2018). People of the Book dan Gagasan Pluralisme Keagamaan dalam Alquran. Wawasan: Jurnal Ilmiah Agama dan Sosial Budaya, 3(2), 140-159. https://doi.org/10.15575/jw.v3i2.3582

Kalay, N. S. (2019). Kristologi “Logos” dan Konteks Pluralisme Agama. Kenosis: Jurnal Kajian Teologi, 1(2), 108128. https://doi.org/10.37196/kenosis.v1i2.24

Keener, C. S. (2003). The Gospel of John A Commentary. United States of America: Hendrickson Publishers.

Knitter, P. F. (2005). Introduction. In P. F. Knitter (Ed.), The Myth of Religious Superiority: Multifaith Explorations of Religious. United States of America: Orbis Books, Maryknoll, New York.

Listijabudi, D. K. (2018). Pembacaan Lintas Tekstual: Tantangan Ber-Hermeneutik Alkitab Asia (1). Gema Teologika: Jurnal Teologi Kontekstual dan Filsafat Keilahian, 3(2), 207. https://doi.org/10.21460/gema.2018.32.411

Listijabudi, D. K. (2019). Pembacaan Lintas Tekstual: Tantangan Ber-Hermeneutik Alkitab Asia (2). Gema Teologika: Jurnal Teologi Kontekstual dan Filsafat Keilahian, 4(1), 73-100. https://doi.org/10.21460/gema.2019.41.412

Lumintang, S. I. (2004). Theologia abu-abu: pluralisme agama: tantangan \& ancaman racun pluralisme dalam teologi Kristen masa kini. Malang: Gandum Mas.

Marbaniang, D. (2007). Theology of Religion: Pluralism, Inclusivism, Exclusivism. Manila.

Moyaert, M. (2011). Summary for Policymakers. In Intergovernmental Panel on Climate Change (Ed.), Climate Change 2013 - The Physical Science Basis (Vol. 53, hal. 1-30). https://doi.org/10.1017/CBO9781107415324.004

Munjid, A. (2009). Mengurai Tumpang-Tindih Pluralisme dan Relativisme. In H. M. dan K. Anwar (Ed.), Prospek Pluralisme Agama di Indonesia. Yogyakarta: Interfidei.

Nurhadi, R., Hadi, S., Thoyib, I. M., \& Suhandano, S. (2013). Dialektika Inklusivisme Dan Eksklusivisme Islam Kajian Semantik Terhadap Tafsir Al-Quran Tentang Hubungan Antaragama. Jurnal Kawistara, 3(1), 58-67. https://doi.org/10.22146/kawistara.3961

Objantoro, E. (2016). Pluralisme agama-agama: Tantangan bagi teologi Kristen. Jurnal Simpson: Jurnal Teologi dan Pendidikan Agama Kristen, 1(1), 61-80.

Parihala, Y., \& Sapteno, K. (2020). Dari Kesaksian Iman ke Simbiosis Agama: Meninjau Konsep Dialog Calvin E. Shenk Bagi Perjumpaan Islam-Kristen di Maluku. Religious: Jurnal Studi Agama-Agama dan Lintas Budaya, 4(2), 103-114. https://doi.org/10.15575/rjsalb.v4i2.8250

Philips, G. (2013). Beyond Pluralism Open Integrity As a Suitable Approach to Muslim-Christian Dialogue (1 ed.; E. J. Sarapung, ed.). Yogyakarta: Interfidei.

Rahman, K., \& Akram, M. (2020). Christian-Muslim Coexistence in Peshawar City. Asian Social Science, 16(4), 30. https://doi.org/10.5539/ass.v16n4p30

Riesebrodt, M. (2010). The Promise of Salvation: A Theory of Religion. United States of America: The University of 


\section{Chicago Press.}

Sirry, M. (2009). Compete with one another in good works: Exegesis of Qur'an Verse 5.48 and contemporary muslim discourses on religious pluralism. Islam and Christian-Muslim Relations, 20(4), 423-438. https://doi.org/10.1080/09596410903194886

Soesilo, Y. (2011). Gereja dan Pluralisme Agama dalam Konteks di Indonesia. Jurnal Antusias, 1(2), 81-93.

Song, C. (2008). Allah yang Turut Menderita (6 ed.). Jakarta: Gunung Mulia.

Sterkens, C. J. A., Hermans, C. A. M., \& Van der Ven, J. A. (1998). Theories about the Relationship Between Religions in Religious Education. In C. Sterkens \& A. Ploeger (Ed.), Education into Realms of Meaning in a Plural Society. Kampen: Kok.

Susanti, A. (2017). Relevansi Finalitas Kristus Di Tengah-Tengah Arus Pluralisme Dan Pluralitas Masyarakat Indonesia. Evangelikal: Jurnal Teologi Injili dan Pembinaan Warga Jemaat, 1(1), 85-102. https://doi.org/10.46445/ejti.v1i1.65

Syamsuddin, S. (2018). Pandangan al-Qur'an tentang Klaim Ekslusif Kebenaran Agama. In Suhadi (Ed.), Costly Tolerance: Tantangan Baru Dialog Muslim-Kriisten Di Indonesia dan Belanda. Yogyakarta: CRCS UGM. and conditions of the Creative Commons Attribution (CC BY SA) license (https://creativecommons.org/licenses/by-sa/3.0/). 
Halaman ini sengaja dikosongkan 